Brit. J. prev. soc. Med. (1959), 13, 14-27

\title{
AIR POLLUTION AND CAUSES OF DEATH
}

\author{
BY \\ CHARLES DALY \\ Ulverston, Lancs.
}

This paper describes a study of the relationship between indices of air pollution and respiratory and other causes of death in the large towns of England and Wales.*

Although there are now well over a thousand instruments measuring air pollution in one way or another in England and Wales, grave difficulties are involved in using their results to measure the average exposure to pollution experienced by the inhabitants of any given town. Many instruments, for instance, have deliberately been sited near known sources of pollution to measure changes in the level of pollution over the years; and few towns have many instruments-Liverpool, for example, had only two in 1954 (Department of Scientific and Industrial Research, 1955)-and there is often considerable variation in the levels indicated.

An attempt has therefore been made to find some better and more meaningful measure of the degree of air pollution to which the inhabitants of any town have been exposed. The indices adopted were based on the quantities of different fuels burnt annually in each town, and the area in which they are burnt.

The 83 county boroughs (C.Bs) of England and Wales were chosen for study because details of the numbers of deaths in these towns have been published or otherwise made available by the General Register Office over a considerable period; 79 of them are in England, and four in Wales, and they vary in size from Canterbury with a population of 28,000 , to Birmingham with a population of over one million, the average (median) being about 110,000 .

* Most of this work was done while the author was a member of the staff of the Social Medicine Research Unit of the Medical Research Council.
Six groups of causes of death have been studied:
(1) Bronchitis
(2) Pneumonia
(3) Respiratory Tuberculosis
(4) Lung Cancer
(5) Other Respiratory Diseases
(6) All Non-Respiratory Diseases.

The standard of diagnosis of these diseases may vary in different parts of the country, but it is felt that this is unlikely to invalidate the results obtained. Any relationship between the "social status" of a town and the diagnostic criteria adopted by its doctors has been taken into account to some extent in the statistical techniques used in the study of social indices. The death rates refer almost entirely to males in the age group 45-64 years and cover the 7-year period, 1948-54. Death rates for the age group 65-74 years refer to the 5-year period 1950-54, since the figures available were less detailed before 1950 . The populations on which the various rates are based are those of the 1951 Census. Details of these death rates have been published by the General Register Office (1957).

\section{Measurement of Fuel Consumption}

Data on the consumption of different types of fuel in the 1,330 local fuel overseer (L.F.O.) areas were published by the Ministry of Fuel and Power (1955). Since most of the county boroughs were complete L.F.O. areas, the required statistics were readily available and access to much unpublished data permitted reasonable estimates to be made of the amount of different types of fuel consumed in each town in, or about, the year May, 1951 to May, 1952. The domestic fuels are house coal, coke, anthracite, and boiler fuel, and the industrial fuels are smokeless solid fuel, other solid fuel, and liquid fuels (i.e. gas/ diesel oil, fuel oil, and creosote/pitch mixture). 
Details of the fuel consumed by the electricity generating stations were also available, but this has not been classed here as "industrial" fuel, the question of air pollution by power stations being dealt with separately. It was unfortunately impossible to obtain any information about air pollution by railways and shipping. (For details of these statistics and methods used to make certain estimates, see Appendix.)

One aim of the inquiry was to differentiate between the effects of smoke and sulphur pollution, and for this purpose the Fuel Research Station of the Department of Scientific and Industrial Research supplied estimates of the amounts of smoke and sulphur dioxide emitted by given quantities of each of the fuels mentioned above. The amount of smoke and sulphur dioxide emitted annually in each C.B. was then estimated on this basis.

\section{Measurement of Area}

The area of a town in which fuel is burnt is the "built-up area". In a previous communication of preliminary results (Daly, 1954), use was made of the total area of each C.B., though it was pointed out that these areas often include considerable portions of agricultural or park land. Subsequent studies showed a great range of variation in the proportion of a town's area which is "built-up". Smethwick, for example, is completely built-up, (according to the definition given below), whereas more than 14,000 of Merthyr Tydfil's 17,760 acres do not appear to be built on at all.

Since no data existed on the exact proportion of built-up area in each C.B., a separate inquiry was undertaken to obtain the relevant information. The Ministry of Housing and Local Government gave access to the 6 in. to the mile maps of present land utilization which had been submitted by each county borough under the Town and Country Planning Act, 1947. Details of the techniques involved in delineating the requisite areas are given in the Appendix, but it can be mentioned here that the work was carried out independently by a geographer, W. T. W. Morgan, B.A., M.Sc. To reach the required figure, built-up areas were defined as all industrial areas, together with residential areas, comprising as a minimum requirement "detached or semi-detached houses with large gardens. Excluded are those areas with detached houses having gardens of more than one-third of an acre, usually not fronting a road."

\section{Measurement of Air Pollution}

In towns of the same built-up area, it is reasonable to assume that there is a direct relationship between the amount of fuel burnt and the level of air pollution. The amount of smoke emitted annually per acre of built-up area was therefore taken as an index of a town's pollution by smoke. A similar procedure gave an index of sulphur pollution, but it was found that these two indices were so highly correlated in the $83 \mathrm{C} . \mathrm{Bs}$, that it was impossible to differentiate between their respective effects, if any. For this reason results for only one set of indices (i.e. domestic smoke and industrial smoke) are presented and the indices have been termed "domestic pollution" and "industrial pollution".* (For values of these indices for each C.B., see Appendix.) The two indices have not been amalgamated to give some general measure of air pollution, since the relationship between each index and the various causes of death seems to differ. On a priori grounds, also, it is not unreasonable to keep the two measures separate. For example, industrial chimneys are not so evenly spread throughout a town as domestic chimneys and the measure of their coal consumption per acre of built-up area may, therefore, be less meaningful. Further, industrial chimneys are very much higher, so that a much greater proportion of their emission is probably dispersed into the atmosphere. It follows that the "arbitrary units" adopted in this paper can validly be used in comparisons between towns but must not be taken to demonstrate the relative magnitudes of the domestic and industrial air pollution effects.

Although a study of domestic and industrial fuel consumption fails to indicate the relative importance of the effects of smoke and sulphur emission on health (as measured by mortality rates), it has been possible to study the problem in another way. Power stations are essentially sulphur-emitting agents, and if pollution from this source is shown to have an effect on health then sulphur would probably be incriminated. Since they are point sources of pollution, however, the techniques used for measuring domestic and industrial pollution are inapplicablè. This particular problem is approached by a different method which is outlined later.

Correlation.-In correlating the indices of pollution with the death rates, one important feature must

\footnotetext{
* For reasons which will be discussed later the logarithm of indus trial smoke per acre has been used as the "industrial pollution" index in the calculation of correlation co-efficients.
} 
be mentioned. When any variables are subject to sampling error, the correlation co-efficient tends to underestimate the true relationship between the two characteristics. Technically, it is said to be "attenuated". Death rates in a town vary from year to year, and even rates based on 7-year data are only estimates of some hypothetical death rates. This fact has had to be taken into account in the results which follow, since six causes of death are dealt with, each affected by attenuation error to a varying extent. When bronchitis death rates are involved, the corrected value of $r$ is 3 per cent. greater than the calculated value; for pneumonia the corresponding figure is 16 per cent.; for respiratory tuberculosis 9 per cent.; for lung cancer 12 per cent.; for other respiratory diseases 29 per cent.; and for all nonrespiratory diseases 5 per cent. ${ }^{*}$ It should be noted, however, that these values may still be under-estimates, since they do not take into account any diagnostic error.

There is no doubt that the air pollution indices are also subject to considerable error, but it is impossible to measure the extent of this, and no attempt has been made to correct the relevant values of $r$. The same applies to the various social indices studied; these are probably imperfect measures of some underlying "social factor", but how imperfect they are is unknown.

\section{EFfects of Domestic and lndustrial Air POLLUTION}

The basic results are presented in Table $\mathrm{I}$, which shows a high correlation between domestic air pollution and five of the six groups of causes of death, including the non-respiratory diseases.

\section{TABLE I}

ASSOCIATION BETWEEN INDICES OF DOMESTIC AND INDUSTRIAL AIR POLLUTION AND DEATH RATES FROM CERTAIN CAUSES IN THE 83 COUNTY BOROUGHS OF ENGLAND AND WALES, MALES AGED 45-64 YEARS; 1948-54

\begin{tabular}{|c|c|c|c|}
\hline \multirow{2}{*}{\multicolumn{2}{|c|}{ Cause of Death }} & \multicolumn{2}{|c|}{ Air Pollution } \\
\hline & & Domestic & Industrial \\
\hline $\begin{array}{l}\text { Bronchitis } \ldots \\
\text { Pneumonia } \ldots \\
\text { Respiratory tuberculosis } \\
\text { Lung cancer } \ldots \\
\text { Other respiratory diseases } \\
\text { All non-respiratory diseases }\end{array}$ & $\begin{array}{l}\ldots \\
\cdots \\
\cdots \\
\cdots\end{array}$ & $\begin{array}{l}0.70(0.68) \\
0.60(0.52) \\
0.59(0.54) \\
0.54(0.48) \\
0.27(0.21) \\
0.50(0.48)\end{array}$ & $\begin{array}{l}0.62(0.60) \\
0 \cdot 52(0 \cdot 45) \\
0 \cdot 22(0 \cdot 20) \\
0 \cdot 20(0 \cdot 18) \\
0 \cdot 01(0 \cdot 01) \\
0 \cdot 35(0 \cdot 33)\end{array}$ \\
\hline
\end{tabular}

Values of the correlation co-efficient $r$ corrected for attenuation error.

Uncorrected values are given in brackets.

* It is hoped to publish a paper describing the mathematical treatment of this problem in due course.
Bronchitis shows the highest degree of association, followed by pneumonia, respiratory tuberculosis, lung cancer, and all non-respiratory diseases-in that order-all showing a substantial association with domestic pollution. Other respiratory diseases show the least close association. Industrial pollution shows a clear association with bronchitis and with pneumonia, rather less with the non-respiratory diseases, and no significant degree of relationship with tuberculosis, lung cancer, and other respiratory diseases.

Bronchitis and lung cancer are probably of most interest here, and Figs 1 and 2 (opposite) present graphically the associations between these causes of death in middle-aged males and the two pollution indices. Bronchitis shows a clear upward trend with domestic air pollution, those towns with low pollution having low rates, and those towns with high pollution tending to have the highest rates. With cancer of the lung there is a slight upward trend, but it is clear that domestic air pollution cannot account for much of the differences in the death rates between the various towns.

Fig. 2 picks out three towns (St. Helens, Middlesbrough, and Stoke-on-Trent) with exceptionally high indices of industrial air pollution (as measured here). Their bronchitis death rates, however, are not correspondingly high-being only a little above the average. The inclusion of these towns in the calculation of the correlation co-efficient would have a disproportionate effect, and the logarithm of "industrial smoke per acre" has therefore been used as the index of industrial air pollution. This procedure is not applied without precedent, since one is accustomed in biological work to encounter "doseresponse curves" in which there is a linear relation between the response and the logarithm of the dose. It is worth noting that the co-efficient measuring the correlation between the bronchitis death rates and the logarithm of the industrial air pollution index is very similar to that obtained when the same death rates are correlated with the unadjusted index of air pollution for all the C.Bs excluding the three already mentioned. Fig. 2A shows a clear upward trend, but Fig. 2B shows only a slight trend.

\section{OCCUPATIONAL FACTORS}

Before further discussing the various features of Table I, some mention should be made of the group of "other respiratory diseases". This miscellaneous group may sometimes include many deaths due to occupational hazards:-Stoke-on-Trent and Merthyr Tydfil have rates of 89 and 131 per 100,000 respectively, while no other town has a rate greater than 


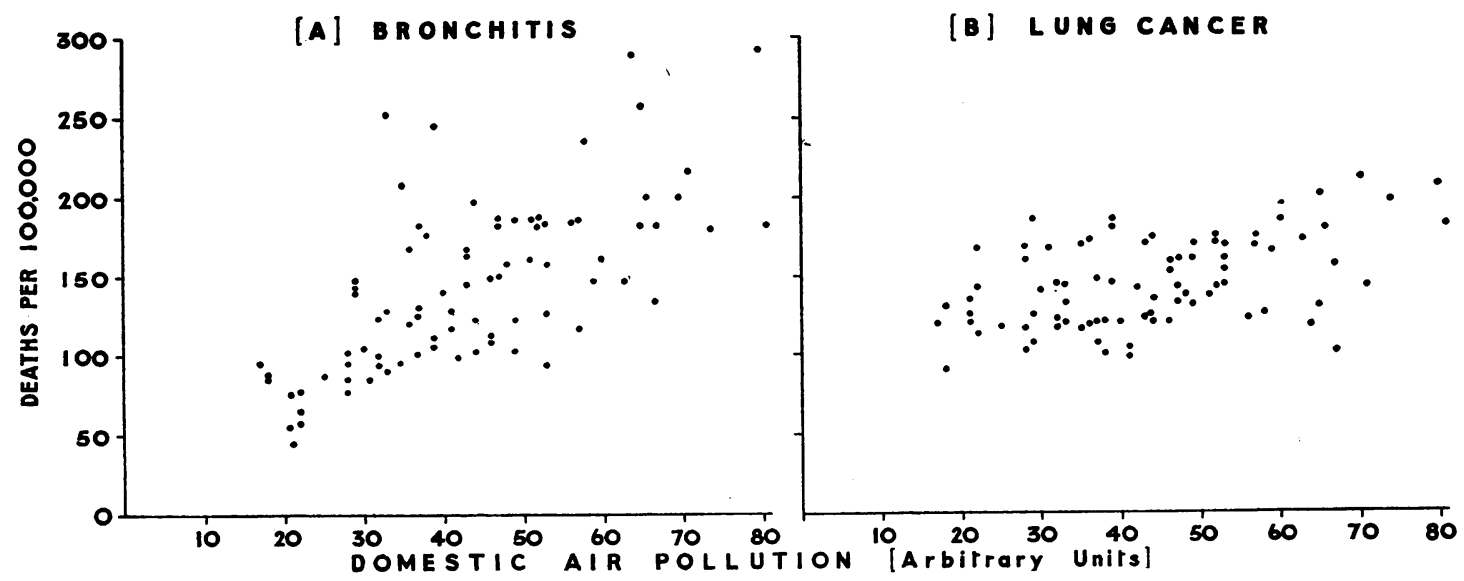

Fig. 1.-Death rate per 100,000 males aged 45 to 64 years from (A) Bronchitis and (B) Lung Cancer related to air pollution in 83 county boroughs.

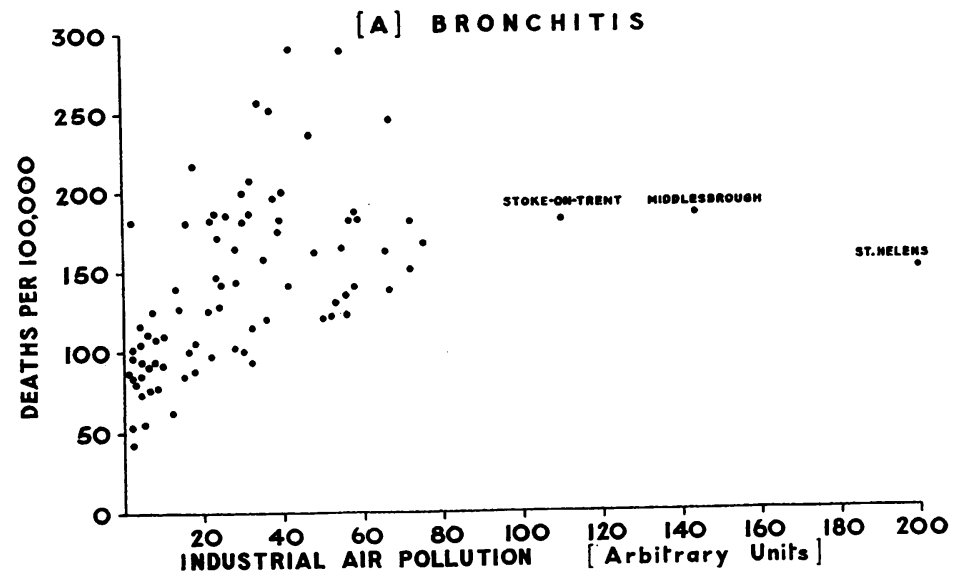

FIG. 2A.-Death rate per 100,000 males aged 45 to 64 years from bronchitis related to industrial air pollution in 83 county boroughs.

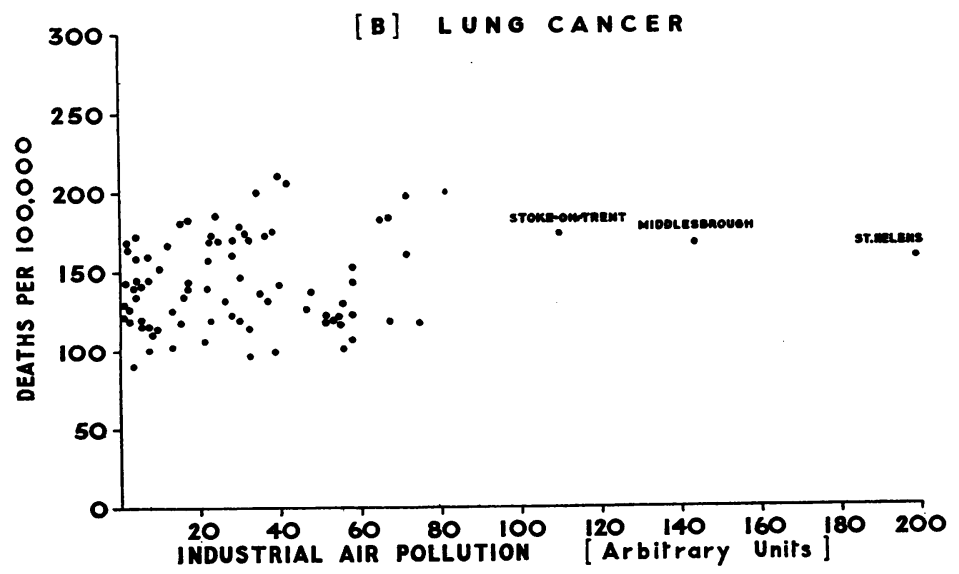

FIG. 2B.-Death rate per 100,000 males aged 45 to 64 years from lung cancer related to industrial air pollution in 83 county boroughs. 
50 per 100,000 . These figures presumably reflect the incidence of silicosis among potters, and of pneumoconiosis among coal miners. In view of this, it is necessary to bear in mind that the rates for "other respiratory diseases" may be distorted by occupational differences between the populations in each town.

That occupational differences probably have little effect on the male death rates from bronchitis is demonstrated by Fig. 3, which compares male and female mortality from bronchitis at ages 45-64 years. With the exception of Oldham and to a lesser extent Bolton, Bury, and Burnley, the points on the scatter diagram all lie very near to a straight line, indicating that the ratio of the male to the female death rate (about 4:1) is approximately the same in each C.B. As far as the four Lancashire towns are concerned, it is not unreasonable to suggest that an occupational factor affects the female cotton workers particularly in Oldham. This is in agreement with some of the work of Schilling (1956) on byssinosis in Oldham.

A similar technique cannot be applied to the comparison of male and female mortality from lung cancer, since the female death rates are based on relatively small numbers of deaths and liable to considerable error. Alternative methods of statistical analysis (Woolf, 1955) do show, however, that after taking these errors into account the ratio of male to female death rates in each town could be constant. (Bury may be a possible exception to this, since in the period studied $5 \cdot 77$ female deaths were to be expected, whereas fifteen actually occurred.)

\section{INFLUENZA EPIDEMICS}

Because epidemics of influenza affect the recorded bronchitis death rates it was thought worthwhile to examine the statistics to see whether this had been important in the period studied-which includes two "flu" years. Ten C.Bs were chosen at random and the numbers of deaths from bronchitis in each town were tabulated for each year separately. A test was then carried out to see if the pattern of deaths between the towns varied from year to year. The resulting value of $\chi^{2}=60 \cdot 77,54$ d.f. $(P=0.25)$ gave no grounds for believing that the inclusion of these "flu" years had noticeably disturbed the pattern of the bronchitis death rates.

\section{OTHER FACTORS}

The chief feature of Table $I$ is the importance of the relationship between both indices of air pollution and the bronchitis death rates. When the combined "effects" of the pollution indices are considered (using the technique of multiple correlation), it is found that they could together account for about 60 per cent. of the existing variation in the death rates between towns. (Since the pollution indices are subject to error, it is probable that this value is an underestimate.) However, no account has yet been taken of the fact that the 83 C.Bs differ greatly in many ways apart from air pollution. The extent of overcrowding, the social structure, and the temperature, humidity, and other climatic factors are all variable. It is impractical for every possible factor to be taken into account, but data from the 1951 Census give indications of the "social" differences. As far as climatic effects are concerned, though the C.Bs on Tyneside compare unfavourably with those on Merseyside and near Manchester as far as temperature* is concerned, they have lower death rates from bronchitis.

For topographical reasons, some towns have more natural fog than others and are therefore more liable to episodes of "smog". It has not been possible, however, to take this into account.

* Tyneside also compares unfavourably with Merseyside and Manchester with regard to overcrowding.

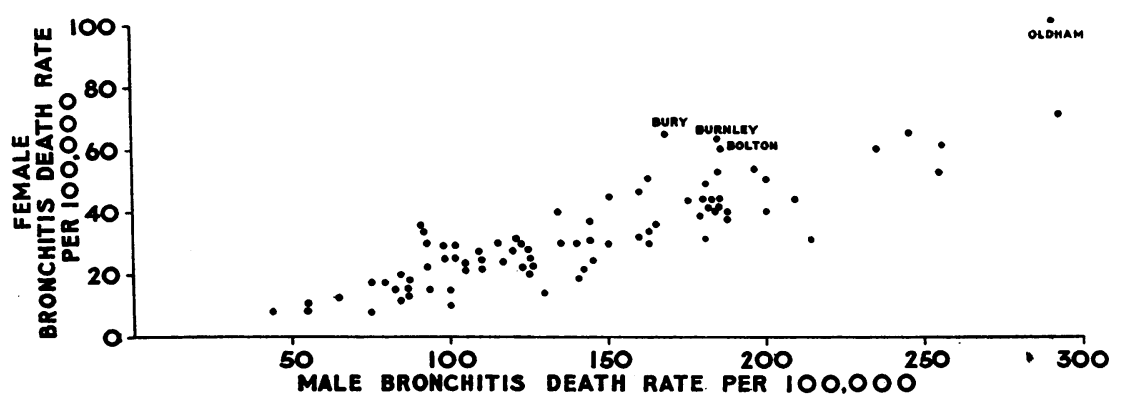

Fig. 3.-Male and female death rates per 100,000 persons aged 45 to 64 years in 83 county boroughs. 
Towns also differ in the amount of air pollution received from external sources. Apart from emissions from its own chimneys, a town such as Bootle must receive pollution from those of its neighbour Liverpool, whereas a town such as Norwich is relatively unaffected by pollution from other areas. To test whether the nature of the surrounding area introduced any bias to the results, the sixteen C.Bs completely surrounded by rural areas were studied. Although these include Warrington, situated between, and only a few miles from, the Manchester and Merseyside "conurbations" the degree of relationship between bronchitis mortality and domestic air pollution is still high-r $=0.55$. (A similar figure is obtained when Warrington is excluded from the analysis.)

Table II shows the association between the death rates and four social indices: (a) "social class" structure; (b) overcrowding; (c) population density; and $(d)$ education.

Calculation of Indices. (For the values for each C.B. see Appendix):

(a) Using the Registrar General's classification of occupations (General Register Office, 1951), and 1951 Census data on the proportions of the five social classes so defined which were to be found in the C.Bs, a score of 1 to 5 was assigned to each of the social classes and a weighted average score was obtained for each C.B. + They ranged from 2.90 in Bournemouth to 3.64 in Bootle.

(b) The index of overcrowding adopted was the proportion of households living more than one person per room. It ranged from $8 \cdot 1$ per cent. in Great Yarmouth to 34.9 per cent. in Gateshead.

(c) From the point of view of spread of infection it may be argued that people living in towns with a high density of population (measured by the number

f Similar results were obtained using "the proportion in Social Classes IV and V". of persons per acre) are more liable to respiratory diseases than people living in towns with a lower density. But any measure of density obtained by dividing the total population by the area of a town is obviously highly correlated with domestic air pollution. The following procedure was used to obtain a more meaningful measure of population density, and one which is less highly related to air pollution, so that it is easier to distinguish between the effects, if any, of both of these factors.

Besides the maps of present land utilization at the Ministry of Housing and Local Government already described, there exist certain statistics about land use, such as the population densities in a number of "areas of similar development" within each town. (These areas might comprise a new council housing estate, or several streets of terraced houses, and so on.) The average (median) of these densities has been taken as the required measure. For instance, the median population density of Stoke-on-Trent is 48.6 persons per acre, which means that half the population live at a lower population density and half at a higher density. The values obtained for the 83 C.Bs ranged from $21 \cdot 3$ persons per acre in Bournemouth to 87.6 persons per acre in Bootle.

(d) The proportion of occupied males in any town who left school before the age of 15 years was used as a measure of differences in education. The proportion ranged from 64.5 per cent. in Plymouth to $87 \cdot 5$ per cent. in Stoke-on-Trent and Warrington.

\section{BRONCHITIS}

Table II shows that with bronchitis the correlation co-efficients are about the same level for the social indices as for the air pollution indices. The highest degree of association appears to be with "educational level" and the lowest, surprisingly, with "population density", but all four social indices are highly inter-related, and it is likely that they are

TABLE II

ASSOCIATION BETWEEN FOUR "SOCIAL" INDICES AND DEATH RATES FROM CERTAIN CAUSES IN THE 83 COUNTY BOROUGHS OF ENGLAND AND WALES. MALES AGED 45-64 YEARS; 1948-54

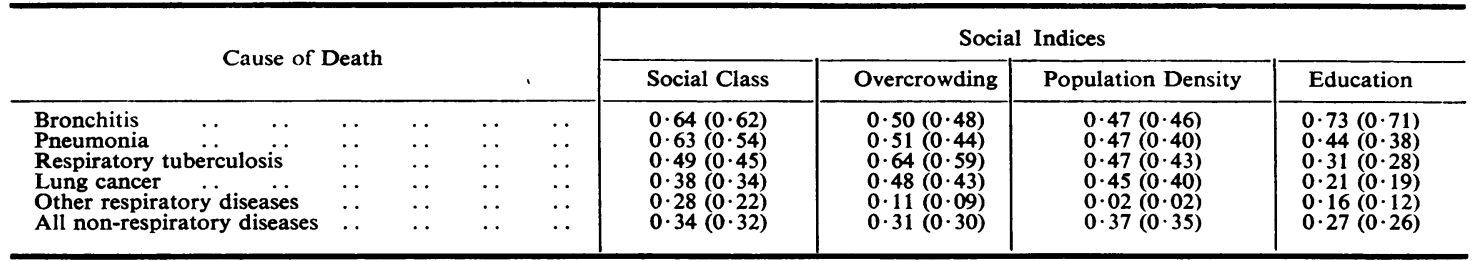

Values of the correlation co-efficient $r$ corrected for attenuation error.

Uncorrected values are given in brackets. 
simply different aspects of a certain factor which in some very complex way, can be thought of as measuring social differences between towns.

While clearly it would be desirable to analyse the data so as to be able to state that a certain proportion of the variation in the bronchitis rates was due to air pollution, and another proportion to social factors, this is not possible with any reasonable degree of precision. Broad conclusions can, however, be drawn. When bronchitis mortality is correlated with domestic and industrial air pollution, and the "effects" of social factors (assuming these to be direct effects) are eliminated, ${ }^{*}$ a correlation co-efficient $r=0.47$ is obtained. When bronchitis mortality is correlated with "social" factors, and the "effects" of air pollution (assuming now that these are direct effects) are eliminated, we obtain $r=0.39$. Both these values are highly significant, indicating that air pollution and social factors have an independent and real effect, and in view of the similarity of these correlation co-efficients, it is not unreasonable to infer that these effects are of similar magnitude. Since it can be shown that about two-thirds of the variation in the bronchitis death rates could be attributed to the combined effects of air pollution and social factors (as measured), it follows that about one-third of the variation in mortality could be attributed to air pollution and about one-third to social factors. In view of the imperfections of the indices used, it is likely that these proportions are under-estimated, but it is not possible with the material available to determine the reasons for the residual third of the variation in mortality.

It can be noted that, in the London area, the Metropolitan Borough with the lowest bronchitis death rates for males aged 45-64 years or 65-74 years is Chelsea, which has both a high "social status" + and an above average level of air pollution - (and incidentally, several large power stations in the near vicinity). It could be inferred from this that air pollution is less important than social factors. However, even if air pollution is implicated in only 30 per cent. of all bronchitis deaths in England and Wales, this is equivalent to more than 7,500 deaths in any one year.

\section{Lung CANCer}

Table I and Figs 1 and 2 have shown that the relationship between lung cancer deaths and air

* Using the "combined partial correlation co-efficient" described by Stouffer (1934). Only two social indices have been used-those giving the highest values of $r$. The addition of the others has a negligiving the high

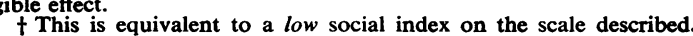

pollution is less than that between bronchitis deaths and air pollution. As far as the present indices are concerned, only about 35 per cent. of the variation in lung cancer mortality between the towns could be attributed to the combined effect of both pollution and social indices. A co-efficient of $r=0.31$ is obtained when the death rates are correlated with air pollution after eliminating the effects of the social indices, and a co-efficient of $r=0.25$ when they are correlated with social indices after eliminating the effects of air pollution. There is, therefore, no indication here that air pollution is a major factor in the aetiology of lung cancer. The fact that domestic air pollution demonstrates a rather higher correlation with this cause of death than does industrial air pollution may be relevant to the hypothesis that the benzpyrene in town air is an aetiological agent; Waller (1952), who made measurements in various towns, expressed the opinion that most of this benzpyrene derived from domestic fires.

If only 35 per cent. of the difference in the lung cancer death rates between county boroughs can be ascribed to differences in air pollution or to "social" differences, can the remainder be ascribed to differences in smoking habits between the towns? In an attempt to answer this question, the results of a market survey study by Research Services Ltd. havebeen used. Their data cover the period August, 1952, to December, 1955. Using the technique of quota sampling, men and women of different ages were interviewed in almost every administrative area in England and Wales and their smoking habits discussed. The following results were confined to males aged 45-64 years. Only one county borough (Dewsbury) was missed in this study. Some of these towns are relatively small, and consequently had few interviews. It was decided therefore to split the towns into eight groups - the first group of eleven towns comprising those with the lowest lung cancer rates for males aged 45-64, and the last group of ten towns comprising those with the highest rates. The results are summarized in Table III (opposite).

There is a considerable range of variation in the lung cancer rates, Group 1 having an average rate of 106 per 100,000 while Group 8 has an average rate of 191 per 100,000 . The trend in the death rates is not, however, repeated to any marked extent in the various indices of smoking habits. As far as the proportions of non-smokers and cigarette smokers only are concerned, there is little indication that the average amount smoked varied very much from one group of towns to another. (This was also the case for males aged 65-74 years.) At the most, if we consider the number of cigarettes smoked per male in these groups of towns, we get an increase of about 
TABLE III

DIFFERENCES IN SMOKING HABITS IN EIGHT GROUPS OF COUNTY BOROUGHS, CLASSIFIED IN ORDER OF INCREASING MALE LUNG CANCER DEATH RATE IN 1948-54 MARKET RESEARCH SURVEY DATA OBTAINED BY RESEARCH SERVICES LTD. (AUG. 1952 TO DEC. 1955) FOR MALES AGED 45-64 YEARS

\begin{tabular}{|c|c|c|c|c|c|c|c|c|c|}
\hline \multirow[b]{2}{*}{ Group } & \multirow{2}{*}{$\begin{array}{c}\text { No. of } \\
\text { County } \\
\text { Boroughs }\end{array}$} & \multirow{2}{*}{$\begin{array}{l}\text { Number of } \\
\text { Persons } \\
\text { Interviewed }\end{array}$} & \multicolumn{2}{|c|}{ Non-Smokers } & \multicolumn{2}{|c|}{ Cigarette Smokers } & \multicolumn{2}{|c|}{ All Smokers } & \multirow[b]{2}{*}{$\begin{array}{c}\text { Average } \\
\text { Lung } \\
\text { Cancer } \\
\text { Death } \\
\text { Rate }\end{array}$} \\
\hline & & & Number & $\begin{array}{l}\text { Per } \\
\text { cent. }\end{array}$ & Number & $\begin{array}{c}\text { Average Number } \\
\text { of Cigarettes } \\
\text { Smoked } t\end{array}$ & Number & $\begin{array}{l}\text { Average Quan- } \\
\text { tity of Cigarette } \\
\text { Equivalents } \\
\text { Smokedt }\end{array}$ & \\
\hline $\begin{array}{l}1 \\
2 \\
3 \\
4 \\
5 \\
6 \\
7 \\
8\end{array}$ & $\begin{array}{l}11 \\
11 \\
10 \\
10 \\
10 \\
10 \\
10 \\
10\end{array}$ & $\begin{array}{l}261 \\
186 \\
201 \\
235 \\
327 \\
395 \\
768 \\
514\end{array}$ & $\begin{array}{c}52 \\
46 \\
35 \\
49 \\
62 \\
69 \\
178 \\
86\end{array}$ & $\begin{array}{l}19.9 \\
24.7 \\
17.4 \\
20.9 \\
19.0 \\
17.5 \\
23.2 \\
16.7\end{array}$ & $\begin{array}{l}174 \\
122 \\
145 \\
162 \\
228 \\
288 \\
523 \\
381\end{array}$ & $\begin{array}{l}14 \cdot 7 \\
15 \cdot 2 \\
15 \cdot 4 \\
15 \cdot 0 \\
16 \cdot 8 \\
14 \cdot 2 \\
16 \cdot 5 \\
16 \cdot 8\end{array}$ & $\begin{array}{l}209 \\
140 \\
166 \\
186 \\
265 \\
326 \\
590 \\
+28\end{array}$ & $\begin{array}{l}16.7 \\
17.6 \\
17.4 \\
17.6 \\
17.5 \\
17.8 \\
18.1 \\
18.3\end{array}$ & $\begin{array}{l}106 \\
118 \\
125 \\
137 \\
147 \\
162 \\
171 \\
191\end{array}$ \\
\hline
\end{tabular}

tThese figures refer to quantities smoked on the day previous to the questionnaire.

18 per cent. related to a 63 per cent. increase in the lung cancer death rate.

It may be of course, that an index of present smoking habits is inadequate and that a measure of smoking habits 30 years ago is more relevant here. This may be so; but to explain away the differential in lung cancer death rates between towns in terms of smoking habits would imply that substantial changes had taken place in the smoking habits of the populations in whole groups of towns. Also, the "proportion of non-smokers" is not tied down to any consideration of the previous day's smoking habits. It seems likely, therefore, that neither differences in domestic or industrial air pollution, in smoking habits, or in social factors, can account for more than a relatively small proportion of the variation observed in the death rates for lung cancer in the various county boroughs.*

In seeking for some other factor which could be responsible for this variation, a number of analyses were carried out. One interesting result which emerged was the fact that lung cancer seemed to be highly related to respiratory tuberculosis, in so far as those towns with a high death rate from one disease tended also to have a high death rate from the other. The relevant value of $r$ is 0.66 (a value which is not altered when social class is taken into account), whereas $r=0.41$ in the comparison of lung cancer with bronchitis, and $r=0 \cdot 27$ in the comparison of lung cancer with pneumonia. If it be postulated that people who have had a certain degree of respiratory tubercular infection are more liable to lung cancer, then the variation between towns in the lung cancer death rate could be attributed, in part at least, to the fact that some towns

\footnotetext{
* It does not follow from this that there is no relation between smoking and lung cancer in individuals. It implies that smoking cannot be the only factor in the aetiology of lung cancer.
}

contained a greater proportion of such people than others-which is highly probable in view of the large variation between these towns in mortality from respiratory tuberculosis. However, it has not been possible to follow up this idea in detail.

Table IV shows a puzzling feature of the data. When the "density aggregates" are studied, a clear trend from rural area to conurbation is discernable for lung cancer but such a trend is practically nonexistent for "all non-respiratory diseases". It is partly on the strength of such tables that air polution has been hitherto considered to be a possible important factor in the aetiology of lung cancer. When the $83 \mathrm{C}$.Bs are classified according to density aggregate in this way, a similar trend appears for lung cancer but not for the non-respiratory diseases. Yet Table I shows that, on the whole, there

TABLE IV

THE VARIATION IN CERTAIN DEATH RATES BY DENSITY AGGREGATES. MALES AGED 45-64 YEARS, ENGLAND AND WALES, 1950-52

(DEATH RATES PER 100,000-RURAL AREAS ALSO TAKEN AS 100)

\begin{tabular}{|c|c|c|c|c|c|}
\hline \multirow{2}{*}{ Cause of Death } & \multirow{2}{*}{$\begin{array}{l}\text { All } \\
\text { Conur- } \\
\text { bations }\end{array}$} & \multicolumn{3}{|c|}{ Urban Areas $\ddagger$} & \multirow{2}{*}{$\begin{array}{l}\text { Rural } \\
\text { Areas }\end{array}$} \\
\hline & & Large & Medium & Small & \\
\hline Bronchitis & 153 & 129 & 112 & 100 & 59 \\
\hline Pneumonia & $\begin{array}{r}259 \\
52\end{array}$ & $\begin{array}{r}219 \\
54\end{array}$ & $\begin{array}{r}190 \\
42\end{array}$ & $\begin{array}{r}169 \\
38\end{array}$ & $\begin{array}{r}100 \\
30\end{array}$ \\
\hline & 173 & 180 & 140 & 127 & 100 \\
\hline Respiratory tuberculosis & 89 & 90 & 76 & 68 & 47 \\
\hline Lung cancer & 159 & 147 & 125 & 113 & 86 \\
\hline $\begin{array}{l}\text { Other respiratory } \\
\text { diseases }\end{array}$ & $\begin{array}{r}185 \\
25 \\
93\end{array}$ & $\begin{array}{r}171 \\
33 \\
122\end{array}$ & $\begin{array}{r}145 \\
26 \\
96\end{array}$ & \begin{tabular}{r|}
131 \\
32 \\
119
\end{tabular} & $\begin{array}{r}100 \\
27 \\
100\end{array}$ \\
\hline $\begin{array}{l}\text { All non-respiratory } \\
\text { diseases }\end{array}$ & $\begin{array}{r}1,067 \\
118\end{array}$ & $\begin{array}{r}1,091 \\
121\end{array}$ & $\begin{array}{r}1,063 \\
118\end{array}$ & $\begin{array}{r}1,055 \\
117\end{array}$ & $\begin{array}{l}904 \\
100\end{array}$ \\
\hline
\end{tabular}

$\ddagger$ The large, medium, and small urban areas have populations greater than 100,000 , between 50,000 and 100,000 , and below 50,000 respectively. 
is rather less correlation between air pollution and lung cancer than between air pollution and nonrespiratory diseases. It would appear from these facts that lung cancer is related in some way to the size of the town, though it is difficult to see how. This has been confirmed by a study of the mortality rates in the $83 \mathrm{C} . \mathrm{Bs}$, which showed a significant association between population and lung cancer mortality but practically none between population and respiratory tuberculosis mortality.

One final point worth bearing in mind before the density aggregates are used to draw conclusions about the effects of air pollution is that the large urban areas (those with a population of 100,000 or more-outside the conurbations) include such relatively non-polluted towns as Blackpool, Bournemouth, Norwich, and Southend.

\section{Other Causes of Death}

One interesting feature of Table $I$ insofar as causes of death other than bronchitis and lung cancer are concerned, is the relatively high correlation between air pollution and all non-respiratory diseases. Neither lung cancer, respiratory tuberculosis, nor other respiratory diseases show any significant correlation with industrial air pollution, yet with the non-respiratory diseases $r=0 \cdot 35$. Although four of the causes of death studied showed closer relationships with domestic air pollution, the value of $r=0.50$ obtained by correlating with the nonrespiratory diseases is very highly significant. One possible explanation is that "good health" is being measured here, and that this is associated with exposure to sunshine, which, in towns, is considerably reduced by air pollution. When the non-respiratory diseases are correlated with both pollution indices, after eliminating the effects of the two main social indices, a value of $r=0.35$ is obtained, which is still relatively high.

Pneumonia shows much the same tendencies as bronchitis, and the relevant correlation co-efficients in Tables I and II are very similar. However, when pneumonia is correlated with both pollution indices, after eliminating the effects of social factors, $r=$ 0.28 which is very much less than the corresponding figure of 0.47 for bronchitis.

Respiratory tuberculosis shows some correlation with domestic air pollution but little with industrial air pollution. As one would expect, it is most highly associated with overcrowding. When correlated with air pollution, after eliminating social factors, $r=0 \cdot 33$.

Other respiratory diseases do not appear to be correlated with any of the indices studied.

\section{Air Pollution by Power Stations}

It has already been remarked that it was impossible to differentiate between the effects of smoke and the effects of sulphur in considering pollution from domestic and industrial sources. A special study was therefore made of power stations, since they are primarily sulphur-producing agents and any harmful effects attributed to them would probably be due to their emission of sulphur products. Unlike domestic chimneys, which are spread fairly evenly throughout a town, power station chimneys can be thought of as point sources of pollution, and the concept of fuel consumed per acre of built-up area is therefore irrelevant. Instead, a detailed study was made of each county borough to find out $(a)$ the proportion of the population living within one mile of a power station, $(b)$ the average amount of sulphur emitted by each station over a period of 11 years, and $(c)$ the heights of the chimney stacks. These were combined in a number of ways to give measures of what might be described as the potential "nuisance value" of the power stations in or near the 83 C.Bs. The results obtained did not indicate that proximity to a power station increases the death rate from bronchitis. For instance, Fig. 4 shows that C.Bs with no power stations (eight had no power station within a mile) have just as high an average bronchitis death rate as those with a veryc high level of power station pollution. The "nuisance? value" index in this case was based on the product of (1) the average annual sulphur emission during the 11 years, 1941-51, (2) the proportion of the population living within one mile of a power station, and (3) the inverse of the average chimney height (taking $100 \mathrm{ft}$. as the minimum, since diffusion

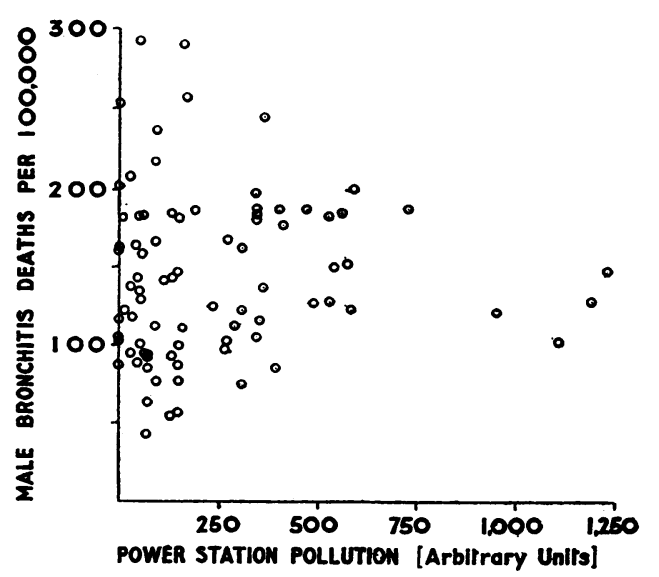

FIG. 4.-Death rate per 100,000 males aged 45 to 64 years from bronchitis related to power station pollution in 83 county boroughs. 
effects will probably be similar below that height). No greater correlation was obtained when various other combinations of these factors were studied. Admittedly, this is an indirect method of measuring power-station pollution, but in considering as many as 83 towns, it is not unreasonable to expect some trend to be apparent if an effect really exists. This work confirms some recent conclusions that power stations make no appreciable difference to the levels of sulphur dioxide in a built-up area (Jarvis and Austin, 1957).

\section{SUMMARY}

Indices of air pollution from domestic and industrial sources in the 83 county boroughs of England and Wales have been calculated, using information about fuel consumption in defined built-up areas. These indices have been correlated with death rates from various respiratory and other diseases among middle-aged males. The results show a relatively close association between these measures of air pollution and bronchitis, and a relatively low association between air pollution and lung cancer. Allowance for social class differences between towns reduces but does not abolish the correlation with bronchitis mortality. Various hypotheses for the variations in mortality are put forward.

An attempt has been made to measure the effect of air pollution from sulphur products by studying the power stations in or near each town. The results give no reason to suppose that proximity to a power station has any noticeable effect on bronchitis mortality.

This study has been made possible by the help and co-operation of many organizations, including the General Register Office, the Ministry of Fuel and Power, the House Coal Distribution (Emergency) Scheme, the Fuel Research Station of the D.S.I.R., the Ministry of Housing and Local Government, the Central Electricity Authority, the Gas Council, the Tobacco Manufacturers' Standing Committee, and the Royal Geographical Society. I should also like to thank Mr. W. T. W. Morgan who gave most invaluable help in calculating the built-up areas, Dr. J. N. Morris and Mr. J. A. Heady for much advice, and Mrs. V. Hall for most of the work of computation.

\section{REFERENCES}

Beaver Committee on Air Pollution (1954). Report, Cmd. 9322. H.M.S.O., London.

Daly, C. (1954). Brit. med. J., 2, 687.

Department of Scientific and Industrial Research. (1955). "The Investigations and Atmospheric Pollution: A Report on Observations in the 10 years ended 31st March, 1954. 27th Report." H.M.S.O., London.

General Register Office (1951). "Classification of Occupations, 1950." H.M.S.O., London.

(1957). Quarterly Return, No. 432, Appendix D (4th Qtr., 1956). H.M.S.O., London.

Jarvis, W. D., and Austin, L. G. (1957). J. Inst. Fuel, 30, 435.

Ministry of Fuel and Power. (1955). "Statistical Digest, 1954." H.M.S.O., London.

Schilling, R. (1956). Personal communication.

Stouffer, S. A. (1934). J. Amer. stat. Ass., 29, 70.

Waller, R. E. (1952). Brit. J. Cancer., 6, 8.

Woolf, B. (1955). Ann. hum. Genet., 19, 251.

\section{APPENDIX}

Fuel Consumption Data.-The sources of data were as follows:

Domestic

(1) HOUSE COAL

(a) Distributed by Merchants.-These data, referring to distribution in "house coal districts", were obtained from the weekly returns of the House Coal Distribution (Emergency) Scheme;

(b) Distributed as Miners' Concessionary Coal. No direct data were available about the distribution by the National Coal Board of miners' coal in each county borough, but the General Register Office made Census material available concerning the number of miners in each town. By multiplying by the average amount of coal received annually by each miner, the required estimates were obtained.

(2) COKE

(a) Distributed by Merchants.-As for 1(a).

(b) Distributed directly by Gasworks.-The Gas Council supplied rough estimates for each county borough.

(3) ANTHRACITE AND BOILER FUEL.-Distributed by merchants, as for $1(a)$.

\section{Industrial}

(1) Data referring to consumption in local fuel overseer areas of both smokeless and other solid fuels were obtained from the Ministry of Fuel and Power's Statistical Digest for 1954. 
(2) Data for liquid fuels (gas/diesel oil, fuel oil, and creosote-pitch mixture) were obtained partly from the same source, and partly from the more detailed records of the Ministry of Fuel and Power.

All these data refer to county boroughs, house coal districts, and local fuel overseer's areas. These do not coincide, but a practical example shows how comparable statistics were obtained for one county borough - the basic unit of area, since the death rates are based on the populations living in each county borough.

In the year May, 1951, to May, 1952, the period to which most of the fuel consumption statistics refer, the merchants in the "house coal district" of Gloucester supplied 51,756 tons of house coal to 35,060 registered premises. This is equivalent to 1.4762 tons per registered premise.

The relevant L.F.O. area comprises Gloucester county borough and Gloucester rural district, and only their total number of registered premises is known, in this case 37,156 . The 1951 Census data showed that there were 18,952 households in the C.B. and 8.904 in the rural district. On the whole, the number of registered premises is proportional to the number of households so calculation gives:

$$
37,156 \times \frac{18,952}{(18,952+8,904)}=25,281 \text { households }
$$

in the county borough as the estimate. It was assumed that these households received the same average quantity of house coal as the 35,060 served by the merchants, giving as a final estimate $25,281 \times 1.4762$ $=37,320$ tons of house coal consumed in the county borough of Gloucester.

A similar procedure was carried out for coke and anthracite, and boiler fuel distributed by merchants, and it was estimated that 6,558 tons of coke and 3,153 tons of anthracite or boiler fuel were also consumed in the county borough in the stated period.

About 4,200 tons of coke were distributed by gasworks to "domestic and other users", and as the proportion going to "domestic users only" was about 33 per cent. in the whole South-Western region, it was assumed that 33 per cent. of $4,200=1,400$ tons were consumed by domestic users in the county borough. The remaining 2,800 tons were included in the industrial fuel statistics.

The number of miners living in Gloucester at the time of the 1951 Census being negligible, the estimation of miners' concessionary coal is best illustrated by a town such as Doncaster, which then contained 2,273 miners aged 15-64 years.
The 612,400 such miners in the whole of England and Wales received a total of $5,200,000$ tons of concessionary coal in $1951 / 52$, so that

$$
2,273 \times \frac{5,200,000}{612,300}=19,300 \text { tons }
$$

may be taken as the amount of coal consumed by miners in this county borough.

Although most of the county boroughs comprised complete L.F.O. areas, some of them had been amalgamated with one or more urban or rural district to form a single L.F.O. area. Since the industrial coal statistics only applied to the latter, it was necessary to make some estimate of the proportion of industrial fuel consumed in the C.B. itself. This was done by using data supplied by the Ministry of Housing and Local Government on the rateable value of industrial hereditaments in each county borough, urban district, and rural district.

For example, Gloucester L.F.O. area consists of Gloucester C.B. and Gloucester R.D., in which the rateable value of the industrial hereditaments were respectively $£ 16,376$ and $£ 19,796$. Since 77,400 tons of nonsmokeless solid fuel were used by industrial consumers in the L.F.O. area, those in the C.B. presumably used

$$
77,400 \times \frac{16,376}{(16,376+19,796)}=35,039 \text { tons. }
$$

A similar procedure was carried out for the other industrial fuels.

Finally, when the fuel used by carbonization and briquetting plants (i.e., gas works, coke ovens, etc.), is burnt, only a small proportion of the products of combustion are released to the atmosphere. The Beaver Committee (1954) shows, for instance, that $27 \cdot 2$ million tons of fuel were supplied to gas works in 1953 , but that only 6.2 million tons of fuel were burnt. Allowance has therefore been made for this effect, though results are complicated by the fact that the fuel burnt in coke ovens consists of a gas, The resulting figures have been included in the indices of "industrial air pollution".

Measurement of Built-up Areas.-The Ministry of Housing and Local Government gave access to the 6-in. to the mile maps of present land utilization which had been submitted under the Town and Country Planning Act, 1947, by each county borough and a number of other towns. These maps have been based on surveys made between 1947 and 1952, most of them being completed between 1949 and 1951 . The following procedure was adopted-all work being carried out independently by $\mathrm{Mr}$. W. T. W. Morgan. 
The industrial and residential areas were traced out in each town, the minimum qualification for a "residential" area being defined beforehand as "detached or semi-detached houses with large gardens. Excluded are those areas with detached houses having gardens of more than one-third of an acre usually not fronting a road". A line was then drawn on the map at an arbitrary distance of half an inch round these areas to eliminate subjective judgment in deciding whether an embayment of open land should be included in the built-up area or whether a detached portion of the town was far enough away to require separate consideration. A similar procedure in reverse determined how much of a large park or waste area in the middle of a town should be included in the built-up area. The use of this "half inch line" does, of course, make the resulting area for any single town slightly artificial, but as this study was designed for purposes of comparison between towns this was felt to be unimportant in comparison with its advantages. The "half inch line" also has the property of over-estimating the extent of a long, irregularly shaped town in comparison with that of a compact town. This means that the air pollution of the former will be under-estimated, which is as it should be, since more will be lost by dispersion. Thus, the indices of air pollution take into account, not only fuel consumption and built-up area, but also to some extent the shape of each town.
When a "pocket" of population exists away from the main part of the town, it is necessary to take into account the population density of each area; otherwise a large but lightly-populated district would have a disproportionate effect on the estimate of built-up area. This has been done by assuming that the population in each separate area consumes the same quantity of domestic fuel per head, calculating the fuel consumption per acre of built-up area for each part separately, and finding the weighted average of these values, using the population in each part as weights.

"ATTENUATION".- The formula used in calculating correlation co-efficients where death rates are compared with pollution or social indices is the usual one, except that the root mean square referring to the death rates in the denominator is given by:

$$
\sqrt{\frac{1}{83} \sum_{1}^{83}\left(R_{1}-\bar{R}\right)^{2}-\frac{82}{(83)^{2}} \sum_{1}^{83} S_{1}{ }^{2}},
$$

where $R_{1}$ refers to the death rates, $\bar{R}$ is the average of these death rates, and $S_{1}{ }^{2}$ refers to the sampling variances of each of these 83 death rates.

This contrasts with the usual term:

$$
\sqrt{\frac{1}{83} \sum_{1}^{83}\left(R_{1}-\bar{R}\right)^{2}}
$$

PARTICULARS OF 83 COUNTY BOROUGHS SHOWING NUMBER OF MALES AGED 45-64 YEARS (AT THE 1951 CENSUS), AIR POLLUTION AND SOCIAL INDICES (IN ARBITRARY UNITS), AND DEATH RATES (PER 100,000) FROM SIX GROUPS,

\begin{tabular}{|c|c|c|c|c|c|c|c|c|c|c|c|c|c|c|c|}
\hline \multirow{2}{*}{\multicolumn{2}{|c|}{ County Borough }} & \multirow[b]{2}{*}{$\begin{array}{l}\text { No. of } \\
\text { Males } \\
\text { aged } \\
45-64\end{array}$} & \multicolumn{3}{|c|}{ Air Pollution } & \multicolumn{4}{|c|}{ Social Index } & \multicolumn{6}{|c|}{ Cause of Death (Rates per 100,000 Males aged 45-64) } \\
\hline & & & $\begin{array}{l}\text { Dom- } \\
\text { estic }\end{array}$ & $\begin{array}{c}\text { Indus- } \\
\text { trial }\end{array}$ & $\mid \begin{array}{c}\text { Power } \\
\text { Sta- } \\
\text { tion }\end{array}$ & $\begin{array}{l}\text { Social } \\
\text { Class }\end{array}$ & $\begin{array}{c}\text { Over- } \\
\text { crowd- } \\
\text { ing }\end{array}$ & $\begin{array}{c}\text { Popula- } \\
\text { tion } \\
\text { Den- } \\
\text { sity }\end{array}$ & $\begin{array}{c}\text { Edu- } \\
\text { ca- } \\
\text { tion }\end{array}$ & $\begin{array}{l}\text { Bron- } \\
\text { chitis }\end{array}$ & $\begin{array}{l}\text { Pneu- } \\
\text { monia }\end{array}$ & $\begin{array}{l}\text { Respi- } \\
\text { ratory } \\
\text { Tuber- } \\
\text { culosis }\end{array}$ & $\begin{array}{l}\text { Cancer } \\
\text { of Lung } \\
\& \text { Bron- } \\
\text { chus }\end{array}$ & $\begin{array}{l}\text { All other } \\
\text { Respira- } \\
\text { tory } \\
\text { Diseases }\end{array}$ & $\begin{array}{l}\text { All Non- } \\
\text { Respi- } \\
\text { ratory } \\
\text { Diseases }\end{array}$ \\
\hline $\begin{array}{l}\text { Barnsley } \\
\text { Barrow-in-Furness } \\
\text { Bath } \ldots\end{array}$ & $\begin{array}{l}\cdots \\
\cdots \\
\cdots\end{array}$ & $\begin{array}{l}8,366 \\
8,157 \\
9,093\end{array}$ & $\begin{array}{l}67 \\
37 \\
21\end{array}$ & $\begin{array}{l}87 \\
86 \\
29\end{array}$ & $\begin{array}{r}47 \\
50 \\
298\end{array}$ & $\begin{array}{l}52 \\
43 \\
16\end{array}$ & $\begin{array}{l}69 \\
41 \\
26\end{array}$ & $\begin{array}{l}54 \\
70 \\
20\end{array}$ & $\begin{array}{l}95 \\
57 \\
19\end{array}$ & $\begin{array}{r}135 \\
130 \\
75\end{array}$ & $\begin{array}{l}48 \\
72 \\
52\end{array}$ & $\begin{array}{l}70 \\
86 \\
50\end{array}$ & $\begin{array}{l}102 \\
119 \\
135\end{array}$ & $\begin{array}{l}20 \\
25 \\
35\end{array}$ & $\begin{array}{r}1059 \\
1168 \\
916\end{array}$ \\
\hline $\begin{array}{ll}\text { Birkenhead } & \ldots \\
\text { Birmingham } & \ldots \\
\text { Blackburn } & \ldots\end{array}$ & $\begin{array}{l}\cdots \\
\cdots \\
\cdots\end{array}$ & $\begin{array}{r}15,113 \\
117,600 \\
13,389\end{array}$ & $\begin{array}{l}53 \\
43 \\
47\end{array}$ & $\begin{array}{l}69 \\
73 \\
70\end{array}$ & $\begin{array}{r}59 \\
137 \\
475\end{array}$ & $\begin{array}{l}50 \\
34 \\
39\end{array}$ & $\begin{array}{l}68 \\
56 \\
16\end{array}$ & $\begin{array}{l}92 \\
46 \\
82\end{array}$ & $\begin{array}{l}60 \\
80 \\
94\end{array}$ & $\begin{array}{l}159 \\
144 \\
187\end{array}$ & $\begin{array}{l}80 \\
60 \\
69\end{array}$ & $\begin{array}{r}115 \\
120 \\
83\end{array}$ & $\begin{array}{l}169 \\
170 \\
132\end{array}$ & $\begin{array}{l}29 \\
30 \\
33\end{array}$ & $\begin{array}{l}1222 \\
1027 \\
1177\end{array}$ \\
\hline $\begin{array}{l}\text { Blackpool } \\
\text { Bolton } \\
\text { Bootle }\end{array}$ & $\begin{array}{l}\cdots \\
\cdots \\
\end{array}$ & $\begin{array}{r}19,736 \\
20,055 \\
7,258\end{array}$ & $\begin{array}{l}46 \\
52 \\
66\end{array}$ & $\begin{array}{l}37 \\
88 \\
74\end{array}$ & $\begin{array}{r}88 \\
400 \\
0\end{array}$ & $\begin{array}{l}18 \\
38 \\
74\end{array}$ & $\begin{array}{l}14 \\
24 \\
93\end{array}$ & $\begin{array}{r}44 \\
53 \\
135\end{array}$ & $\begin{array}{l}58 \\
91 \\
76\end{array}$ & $\begin{array}{l}112 \\
187 \\
201\end{array}$ & $\begin{array}{l}26 \\
55 \\
67\end{array}$ & $\begin{array}{r}72 \\
61 \\
154\end{array}$ & $\begin{array}{l}119 \\
143 \\
179\end{array}$ & $\begin{array}{l}22 \\
37 \\
26\end{array}$ & $\begin{array}{l}1285 \\
1250 \\
1044\end{array}$ \\
\hline $\begin{array}{l}\text { Bournemouth. } \\
\text { Bradford } \quad \ldots \\
\text { Brighton } \quad \ldots\end{array}$ & $\begin{array}{l}\cdots \\
\cdots \\
\cdots\end{array}$ & $\begin{array}{l}16,226 \\
34,099 \\
17,577\end{array}$ & $\begin{array}{l}18 \\
47 \\
28\end{array}$ & $\begin{array}{r}2 \\
80 \\
16\end{array}$ & $\begin{array}{r}0 \\
524 \\
0\end{array}$ & $\begin{array}{r}0 \\
34 \\
22\end{array}$ & $\begin{array}{l}19 \\
53 \\
38\end{array}$ & $\begin{array}{r}3 \\
55 \\
97\end{array}$ & $\begin{array}{l}29 \\
62 \\
46\end{array}$ & $\begin{array}{r}87 \\
183 \\
102\end{array}$ & $\begin{array}{l}26 \\
65 \\
33\end{array}$ & $\begin{array}{l}85 \\
76 \\
77\end{array}$ & $\begin{array}{l}130 \\
142 \\
167\end{array}$ & $\begin{array}{l}26 \\
22 \\
24\end{array}$ & $\begin{array}{l}1017 \\
1223 \\
1062\end{array}$ \\
\hline
\end{tabular}
OF CAUSES

NOTES: Domestic Pollution-100 $P_{1}$, where $P_{1}=$ tons of smoke produced per annum by domestic fuels per acre of built-up area. Industrial Pollution-50 ( $\left.\log P_{2}+2\right)$, where $P_{2}=$ tons of smoke produced per annum by industrial fuels per acre of built-up area. Power Station Pollution is defined in the text.

Social Class-100 $\left(S_{1}-2.9\right)$, where $S_{1}=$ the weighted social class score defined in the text.

Overcrowding-5 $\left(S_{2}-8\right)$, where $S_{2}=$ percentage of households living more than one person per room.

Population Density-2 $\left(S_{3}-20\right)$, where $S_{3}$ is expressed in terms of persons per acre.

Education $-4\left(S_{4}-60\right)$, where $S_{4}=$ percentage of occupied males who left school before the age of 15 years. 
(contin.)

\begin{tabular}{|c|c|c|c|c|c|c|c|c|c|c|c|c|c|c|c|c|}
\hline \multirow{2}{*}{\multicolumn{3}{|c|}{ County Borough }} & \multirow[b]{2}{*}{$\begin{array}{c}\text { No. of } \\
\text { Males } \\
\text { aged } \\
45-64\end{array}$} & \multicolumn{3}{|c|}{ Air Pollution } & \multicolumn{4}{|c|}{ Social Index } & \multicolumn{6}{|c|}{ Cause of Death (Rates per 100,000 Males aged 45-64) } \\
\hline & & & & $\begin{array}{l}\text { Dom- } \\
\text { estic }\end{array}$ & $\begin{array}{c}\text { Indus - } \\
\text { trial }\end{array}$ & $\begin{array}{c}\text { Power } \\
\text { Sta- } \\
\text { tion }\end{array}$ & $\begin{array}{l}\text { Social } \\
\text { Class }\end{array}$ & $\begin{array}{c}\text { Over- } \\
\text { crowd- } \\
\text { ing }\end{array}$ & $\begin{array}{c}\text { Popula- } \\
\text { tion } \\
\text { Den- } \\
\text { sity }\end{array}$ & $\begin{array}{c}\text { Edu- } \\
\text { ca- } \\
\text { tion }\end{array}$ & $\begin{array}{l}\text { Bron- } \\
\text { chitis }\end{array}$ & $\begin{array}{l}\text { Pneu- } \\
\text { monia }\end{array}$ & $\begin{array}{l}\text { Respi- } \\
\text { ratory } \\
\text { Tuber- } \\
\text { culosis } \\
\end{array}$ & $\begin{array}{c}\text { Cancer } \\
\text { of Lung } \\
\text { \& Bron- } \\
\text { chus }\end{array}$ & $\begin{array}{c}\text { All other } \\
\text { Respira- } \\
\text { tory } \\
\text { Diseases }\end{array}$ & \multirow{2}{*}{\begin{tabular}{|c}
$\begin{array}{c}\text { All Non- } \\
\text { Respi- } \\
\text { ratory } \\
\text { Diseases }\end{array}$ \\
$\begin{array}{r}997 \\
1313 \\
1110\end{array}$
\end{tabular}} \\
\hline $\begin{array}{l}\text { Bristol } \\
\text { Burnley } \\
\text { Burton-upon- }\end{array}$ & $\ddot{\text { Trent }}$ & $\begin{array}{l}\cdots \\
\cdots \\
\cdots\end{array}$ & $\begin{array}{r}49,703 \\
10,444 \\
5,684 \\
\end{array}$ & $\begin{array}{l}33 \\
56 \\
29\end{array}$ & $\begin{array}{l}62 \\
88 \\
88\end{array}$ & $\begin{array}{r}44 \\
135 \\
360\end{array}$ & $\begin{array}{l}33 \\
41 \\
54\end{array}$ & $\begin{array}{l}31 \\
20 \\
22\end{array}$ & $\begin{array}{r}35 \\
100 \\
27\end{array}$ & $\begin{array}{l}56 \\
98 \\
66\end{array}$ & $\begin{array}{r}89 \\
185 \\
141\end{array}$ & $\begin{array}{l}52 \\
64 \\
63\end{array}$ & $\begin{array}{r}82 \\
92 \\
106\end{array}$ & $\begin{array}{l}143 \\
122 \\
106\end{array}$ & $\begin{array}{l}48 \\
26 \\
18\end{array}$ & \\
\hline $\begin{array}{l}\text { Bury . . } \\
\text { Canterbury } \\
\text { Carlisle }\end{array}$ & $\begin{array}{l}\cdots \\
\cdots \\
\cdots\end{array}$ & $\begin{array}{l}\cdots \\
\cdots \\
\cdots\end{array}$ & $\begin{array}{l}7,065 \\
2,901 \\
7,673\end{array}$ & $\begin{array}{l}36 \\
17 \\
44\end{array}$ & $\begin{array}{l}94 \\
39 \\
60\end{array}$ & $\begin{array}{r}272 \\
73 \\
1,104 \\
\end{array}$ & $\begin{array}{l}40 \\
24 \\
35\end{array}$ & $\begin{array}{l}19 \\
14 \\
65\end{array}$ & $\begin{array}{l}54 \\
30 \\
39\end{array}$ & $\begin{array}{l}84 \\
54 \\
68\end{array}$ & $\begin{array}{r}168 \\
94 \\
102\end{array}$ & $\begin{array}{l}32 \\
10 \\
32\end{array}$ & $\begin{array}{l}55 \\
79 \\
97\end{array}$ & $\begin{array}{l}117 \\
118 \\
134\end{array}$ & $\begin{array}{l}47 \\
39 \\
26\end{array}$ & $\begin{array}{r}1323 \\
970 \\
1314\end{array}$ \\
\hline $\begin{array}{l}\text { Chester } \\
\text { Coventry } \\
\text { Croydon }\end{array}$ & $\begin{array}{l}\cdots \\
\cdots \\
\cdots\end{array}$ & $\begin{array}{l}\cdots \\
\cdots \\
\cdots\end{array}$ & $\begin{array}{r}5,458 \\
29,173 \\
28,021\end{array}$ & $\begin{array}{l}39 \\
35 \\
30\end{array}$ & $\begin{array}{l}61 \\
75 \\
33 \\
\end{array}$ & $\begin{array}{r}0 \\
24 \\
342\end{array}$ & $\begin{array}{r}31 \\
32 \\
8\end{array}$ & $\begin{array}{l}64 \\
42 \\
20\end{array}$ & $\begin{array}{l}58 \\
34 \\
35\end{array}$ & $\begin{array}{l}56 \\
75 \\
24\end{array}$ & $\begin{array}{r}105 \\
95 \\
105\end{array}$ & $\begin{array}{l}47 \\
40 \\
35\end{array}$ & $\begin{array}{r}105 \\
87 \\
63\end{array}$ & $\begin{array}{l}181 \\
116 \\
140\end{array}$ & $\begin{array}{l}10 \\
29 \\
15\end{array}$ & $\begin{array}{r}1169 \\
1006 \\
901\end{array}$ \\
\hline $\begin{array}{l}\text { Darlington } \\
\text { Derby - . } \\
\text { Dewsbury }\end{array}$ & $\begin{array}{l}\cdots \\
\cdots \\
\cdots\end{array}$ & $\begin{array}{l}\cdots \\
\cdots \\
\cdots\end{array}$ & $\begin{array}{r}9,892 \\
16,208 \\
5,988\end{array}$ & $\begin{array}{l}41 \\
49 \\
38 \\
\end{array}$ & $\begin{array}{l}76 \\
87 \\
79\end{array}$ & $\begin{array}{l}351 \\
581 \\
415\end{array}$ & $\begin{array}{l}33 \\
40 \\
39\end{array}$ & $\begin{array}{l}60 \\
29 \\
62\end{array}$ & $\begin{array}{l}71 \\
57 \\
37\end{array}$ & $\begin{array}{l}66 \\
79 \\
84\end{array}$ & $\begin{array}{l}116 \\
124 \\
177\end{array}$ & $\begin{array}{l}42 \\
50 \\
55\end{array}$ & $\begin{array}{l}78 \\
75 \\
55\end{array}$ & $\begin{array}{r}97 \\
130 \\
100\end{array}$ & $\begin{array}{l}19 \\
35 \\
17\end{array}$ & $\begin{array}{l}1142 \\
1069 \\
1257\end{array}$ \\
\hline $\begin{array}{l}\text { Doncaster } \\
\text { Dudley } \\
\text { Eastbourne }\end{array}$ & $\begin{array}{l}\cdots \\
\cdots \\
\cdots\end{array}$ & $\begin{array}{l}\cdots \\
\cdots \\
\cdots\end{array}$ & $\begin{array}{r}10,082 \\
6,799 \\
6,200\end{array}$ & $\begin{array}{l}44 \\
33 \\
21 \\
\end{array}$ & $\begin{array}{l}86 \\
78 \\
18 \\
\end{array}$ & $\begin{array}{r}13 \\
0 \\
67\end{array}$ & $\begin{array}{r}34 \\
44 \\
9\end{array}$ & $\begin{array}{r}22 \\
74 \\
4\end{array}$ & $\begin{array}{l}43 \\
40 \\
24 \\
\end{array}$ & $\begin{array}{l}63 \\
99 \\
32\end{array}$ & $\begin{array}{r}123 \\
254 \\
44\end{array}$ & $\begin{array}{l}40 \\
63 \\
41\end{array}$ & $\begin{array}{l}72 \\
92 \\
62\end{array}$ & $\begin{array}{l}119 \\
132 \\
120\end{array}$ & $\begin{array}{l}30 \\
25 \\
25\end{array}$ & $\begin{array}{r}1082 \\
976 \\
963\end{array}$ \\
\hline $\begin{array}{l}\text { East Ham } \\
\text { Exeter. . } \\
\text { Gateshead }\end{array}$ & $\begin{array}{l}\cdots \\
\cdots \\
\cdots\end{array}$ & $\begin{array}{l}\cdots \\
\cdots \\
\cdots\end{array}$ & $\begin{array}{r}13,618 \\
8,563 \\
12,107\end{array}$ & $\begin{array}{l}57 \\
18 \\
71\end{array}$ & $\begin{array}{l}29 \\
24 \\
62 \\
\end{array}$ & $\begin{array}{r}0 \\
71 \\
92 \\
\end{array}$ & $\begin{array}{l}45 \\
22 \\
51\end{array}$ & $\begin{array}{r}46 \\
28 \\
134\end{array}$ & $\begin{array}{r}80 \\
34 \\
111 \\
\end{array}$ & $\begin{array}{l}87 \\
45 \\
91\end{array}$ & $\begin{array}{r}117 \\
85 \\
218\end{array}$ & $\begin{array}{l}56 \\
33 \\
59\end{array}$ & $\begin{array}{r}78 \\
80 \\
153\end{array}$ & $\begin{array}{r}172 \\
90 \\
142\end{array}$ & $\begin{array}{l}19 \\
30 \\
26\end{array}$ & $\begin{array}{r}952 \\
1179 \\
1215\end{array}$ \\
\hline $\begin{array}{l}\text { Gloucester } \\
\text { Great Yarmou } \\
\text { Grimsby }\end{array}$ & uth & $\begin{array}{l}\cdots \\
\cdots \\
\cdots\end{array}$ & $\begin{array}{r}7,295 \\
5,500 \\
10,088 \\
\end{array}$ & $\begin{array}{l}29 \\
28 \\
49 \\
\end{array}$ & $\begin{array}{l}56 \\
42 \\
72\end{array}$ & $\begin{array}{r}114 \\
74 \\
268 \\
\end{array}$ & $\begin{array}{l}28 \\
42 \\
58\end{array}$ & $\begin{array}{r}38 \\
1 \\
36\end{array}$ & $\begin{array}{l}62 \\
67 \\
24\end{array}$ & $\begin{array}{l}46 \\
80 \\
84\end{array}$ & $\begin{array}{r}141 \\
94 \\
103\end{array}$ & $\begin{array}{l}57 \\
26 \\
57\end{array}$ & $\begin{array}{r}108 \\
68 \\
99\end{array}$ & $\begin{array}{l}125 \\
101 \\
159\end{array}$ & $\begin{array}{l}23 \\
26 \\
30\end{array}$ & $\begin{array}{l}1159 \\
1031 \\
1137\end{array}$ \\
\hline $\begin{array}{l}\text { Halifax } \\
\text { Hastings } \\
\text { Huddersfield }\end{array}$ & $\begin{array}{l}\cdots \\
\cdots \\
\cdots\end{array}$ & $\begin{array}{l}\cdots \\
\cdots \\
\cdots\end{array}$ & $\begin{array}{r}11,670 \\
6,736 \\
15,970\end{array}$ & $\begin{array}{l}51 \\
21 \\
32\end{array}$ & $\begin{array}{r}84 \\
7 \\
85\end{array}$ & $\begin{array}{l}305 \\
125 \\
304\end{array}$ & $\begin{array}{l}33 \\
18 \\
30\end{array}$ & $\begin{array}{l}48 \\
13 \\
42\end{array}$ & $\begin{array}{l}36 \\
21 \\
25\end{array}$ & $\begin{array}{l}72 \\
42 \\
74\end{array}$ & $\begin{array}{r}162 \\
55 \\
123\end{array}$ & $\begin{array}{l}40 \\
45 \\
36\end{array}$ & $\begin{array}{l}71 \\
91 \\
44\end{array}$ & $\begin{array}{l}136 \\
121 \\
122\end{array}$ & $\begin{array}{l}38 \\
25 \\
23\end{array}$ & $\begin{array}{l}1322 \\
1008 \\
1244\end{array}$ \\
\hline $\begin{array}{l}\text { Ipswich } \\
\text { Kingston-upon } \\
\text { Leeds . . } \\
\end{array}$ & in-Hull & & $\begin{array}{l}11,675 \\
30,930 \\
58,306 \\
\end{array}$ & $\begin{array}{l}25 \\
52 \\
49 \\
\end{array}$ & $\begin{array}{l}59 \\
75 \\
68\end{array}$ & $\begin{array}{l}143 \\
347 \\
733\end{array}$ & $\begin{array}{l}32 \\
57 \\
31\end{array}$ & $\begin{array}{l}14 \\
50 \\
42\end{array}$ & $\begin{array}{l}20 \\
60 \\
44\end{array}$ & $\begin{array}{l}62 \\
82 \\
75\end{array}$ & $\begin{array}{r}86 \\
187 \\
186\end{array}$ & $\begin{array}{r}37 \\
101 \\
61\end{array}$ & $\begin{array}{r}40 \\
118 \\
96\end{array}$ & $\begin{array}{l}117 \\
174 \\
170\end{array}$ & $\begin{array}{l}21 \\
16 \\
27\end{array}$ & $\begin{array}{r}875 \\
1128 \\
1142\end{array}$ \\
\hline $\begin{array}{l}\text { Leicester } \\
\text { Lincoln } \\
\text { Liverpool }\end{array}$ & $\begin{array}{l}\ldots \\
\cdots \\
\cdots \\
\end{array}$ & $\begin{array}{l}\cdots \\
\cdots \\
\cdots\end{array}$ & $\begin{array}{r}32,286 \\
7,899 \\
77,461 \\
\end{array}$ & $\begin{array}{l}42 \\
37 \\
70 \\
\end{array}$ & $\begin{array}{l}67 \\
74 \\
80\end{array}$ & $\begin{array}{r}264 \\
59 \\
588\end{array}$ & $\begin{array}{l}26 \\
30 \\
58\end{array}$ & $\begin{array}{l}22 \\
24 \\
81\end{array}$ & $\begin{array}{r}78 \\
62 \\
128\end{array}$ & $\begin{array}{l}78 \\
64 \\
73\end{array}$ & $\begin{array}{r}98 \\
101 \\
200\end{array}$ & $\begin{array}{l}41 \\
36 \\
71\end{array}$ & $\begin{array}{r}98 \\
96 \\
149\end{array}$ & $\begin{array}{l}140 \\
119 \\
210\end{array}$ & $\begin{array}{l}27 \\
14 \\
32\end{array}$ & $\begin{array}{l}1007 \\
1024 \\
1215\end{array}$ \\
\hline $\begin{array}{l}\text { Manchester } \\
\text { Middlesbrougl }\end{array}$ & & $\begin{array}{l}\cdots \\
\cdots\end{array}$ & $\begin{array}{l}75,426 \\
15,234\end{array}$ & $\begin{array}{l}65 \\
57\end{array}$ & $\begin{array}{r}77 \\
108 \\
\end{array}$ & $\begin{array}{l}166 \\
186\end{array}$ & $\begin{array}{l}40 \\
59\end{array}$ & $\begin{array}{l}38 \\
72\end{array}$ & $\begin{array}{r}56 \\
112\end{array}$ & $\begin{array}{l}79 \\
68\end{array}$ & $\begin{array}{l}258 \\
186\end{array}$ & $\begin{array}{l}68 \\
88\end{array}$ & $\begin{array}{l}142 \\
119\end{array}$ & $\begin{array}{l}201 \\
168\end{array}$ & $\begin{array}{l}34 \\
40\end{array}$ & $\begin{array}{l}1215 \\
1249\end{array}$ \\
\hline $\begin{array}{l}\text { Newcastle-upo } \\
\text { Northampton } \\
\text { Norwich }\end{array}$ & $\begin{array}{l}\text { on-Tyne } \\
\ldots \\
\cdots\end{array}$ & \begin{tabular}{l|} 
\\
$\cdots$ \\
$\cdots$
\end{tabular} & $\begin{array}{l}32,371 \\
12,487 \\
13,676\end{array}$ & $\begin{array}{l}63 \\
41 \\
28\end{array}$ & $\begin{array}{l}68 \\
56 \\
39\end{array}$ & $\begin{array}{r}1,237 \\
530 \\
146\end{array}$ & $\begin{array}{l}37 \\
22 \\
32\end{array}$ & $\begin{array}{r}104 \\
23 \\
23\end{array}$ & $\begin{array}{l}90 \\
36 \\
30\end{array}$ & $\begin{array}{l}65 \\
82 \\
64\end{array}$ & $\begin{array}{r}148 \\
128 \\
76\end{array}$ & $\begin{array}{l}54 \\
32 \\
37\end{array}$ & $\begin{array}{r}126 \\
87 \\
71\end{array}$ & $\begin{array}{l}172 \\
102 \\
116\end{array}$ & $\begin{array}{l}30 \\
15 \\
30\end{array}$ & $\begin{array}{r}1191 \\
976 \\
903\end{array}$ \\
\hline $\begin{array}{l}\text { Nottingham } \\
\text { Oldham } \\
\text { Oxford }\end{array}$ & $\begin{array}{l}\cdots \\
\cdots \\
\cdots\end{array}$ & $\begin{array}{l}\cdots \\
\cdots \\
\cdots\end{array}$ & $\begin{array}{l}32,501 \\
14,309 \\
11,003\end{array}$ & $\begin{array}{l}59 \\
64 \\
22\end{array}$ & $\begin{array}{l}81 \\
87 \\
54\end{array}$ & $\begin{array}{r}147 \\
159 \\
76\end{array}$ & $\begin{array}{l}42 \\
48 \\
25\end{array}$ & $\begin{array}{l}39 \\
42 \\
29\end{array}$ & $\begin{array}{l}47 \\
98 \\
13\end{array}$ & $\begin{array}{r}85 \\
106 \\
42\end{array}$ & $\begin{array}{r}147 \\
290 \\
64\end{array}$ & $\begin{array}{l}64 \\
66 \\
35\end{array}$ & $\begin{array}{r}100 \\
80 \\
51\end{array}$ & $\begin{array}{l}163 \\
117 \\
166\end{array}$ & $\begin{array}{l}23 \\
24 \\
30\end{array}$ & $\begin{array}{r}1016 \\
1241 \\
926\end{array}$ \\
\hline $\begin{array}{l}\text { Plymouth } \\
\text { Portsmouth } \\
\text { Preston }\end{array}$ & $\begin{array}{l}\cdots \\
\cdots \\
\cdots\end{array}$ & $\begin{array}{l}\cdots \\
\cdots \\
\cdots\end{array}$ & $\begin{array}{l}22,851 \\
24,663 \\
13,534\end{array}$ & $\begin{array}{l}22 \\
39 \\
53\end{array}$ & $\begin{array}{l}44 \\
43 \\
88\end{array}$ & $\begin{array}{r}95 \\
294 \\
560\end{array}$ & $\begin{array}{l}38 \\
30 \\
47\end{array}$ & $\begin{array}{l}51 \\
27 \\
44\end{array}$ & $\begin{array}{l}66 \\
78 \\
65\end{array}$ & $\begin{array}{l}18 \\
40 \\
93\end{array}$ & $\begin{array}{r}77 \\
111 \\
185\end{array}$ & $\begin{array}{l}53 \\
45 \\
65\end{array}$ & $\begin{array}{l}92 \\
88 \\
92\end{array}$ & $\begin{array}{l}112 \\
144 \\
152\end{array}$ & $\begin{array}{l}33 \\
19 \\
28\end{array}$ & $\begin{array}{l}1174 \\
1060 \\
1241\end{array}$ \\
\hline $\begin{array}{l}\text { Reading } \\
\text { Rochdale } \\
\text { Rotherham }\end{array}$ & $\begin{array}{l}\cdots \\
\cdots \\
\cdots\end{array}$ & $\begin{array}{l}\cdots \\
\cdots \\
\cdots\end{array}$ & $\begin{array}{r}12,753 \\
10,790 \\
9,258\end{array}$ & $\begin{array}{l}22 \\
43 \\
33\end{array}$ & $\begin{array}{l}34 \\
87 \\
68\end{array}$ & $\begin{array}{r}143 \\
40 \\
1,194 \\
\end{array}$ & $\begin{array}{l}29 \\
44 \\
52\end{array}$ & $\begin{array}{l}37 \\
30 \\
52\end{array}$ & $\begin{array}{l}41 \\
56 \\
46\end{array}$ & $\begin{array}{l}52 \\
87 \\
92\end{array}$ & $\begin{array}{r}56 \\
164 \\
128\end{array}$ & $\begin{array}{l}48 \\
33 \\
42\end{array}$ & $\begin{array}{l}72 \\
77 \\
77\end{array}$ & $\begin{array}{l}141 \\
122 \\
119\end{array}$ & $\begin{array}{l}15 \\
40 \\
17\end{array}$ & $\begin{array}{r}906 \\
1290 \\
1047\end{array}$ \\
\hline $\begin{array}{l}\text { St. Helens } \\
\text { Salford } \\
\text { Sheffield }\end{array}$ & $\begin{array}{l}\cdots \\
\cdots \\
\cdots\end{array}$ & $\begin{array}{l}\cdots \\
\cdots \\
\cdots\end{array}$ & $\begin{array}{l}12,407 \\
18,527 \\
59,787\end{array}$ & $\begin{array}{l}46 \\
80 \\
47\end{array}$ & $\begin{array}{r}115 \\
81 \\
93\end{array}$ & $\begin{array}{r}540 \\
56 \\
577 \\
\end{array}$ & $\begin{array}{l}64 \\
55 \\
40 \\
\end{array}$ & $\begin{array}{l}89 \\
56 \\
42\end{array}$ & $\begin{array}{r}134 \\
119 \\
46\end{array}$ & $\begin{array}{r}103 \\
103 \\
93\end{array}$ & $\begin{array}{l}150 \\
292 \\
151\end{array}$ & $\begin{array}{l}55 \\
68 \\
59\end{array}$ & $\begin{array}{r}94 \\
149 \\
81\end{array}$ & $\begin{array}{l}157 \\
206 \\
160\end{array}$ & $\begin{array}{l}35 \\
48 \\
27\end{array}$ & $\begin{array}{l}1133 \\
1279 \\
1072\end{array}$ \\
\hline $\begin{array}{l}\text { Smethwick } \\
\text { Southampton } \\
\text { Southend-on- }\end{array}$ & Sea & $\begin{array}{l}\cdots \\
\cdots \\
\cdots \\
\end{array}$ & $\begin{array}{r}8,449 \\
19,900 \\
16,763\end{array}$ & $\begin{array}{l}60 \\
28 \\
31 \\
\end{array}$ & $\begin{array}{l}91 \\
33 \\
14 \\
\end{array}$ & $\begin{array}{r}0 \\
397 \\
37\end{array}$ & $\begin{array}{r}38 \\
31 \\
6 \\
\end{array}$ & $\begin{array}{l}40 \\
45 \\
14 \\
\end{array}$ & $\begin{array}{l}37 \\
31 \\
36\end{array}$ & $\begin{array}{l}93 \\
61 \\
22\end{array}$ & $\begin{array}{r}162 \\
85 \\
84\end{array}$ & $\begin{array}{l}52 \\
44 \\
42\end{array}$ & $\begin{array}{r}144 \\
124 \\
68\end{array}$ & $\begin{array}{l}183 \\
159 \\
166\end{array}$ & $\begin{array}{l}36 \\
33 \\
23\end{array}$ & $\begin{array}{r}1038 \\
1092 \\
965\end{array}$ \\
\hline $\begin{array}{l}\text { Southport } \\
\text { South Shields } \\
\text { Stockport }\end{array}$ & $\begin{array}{l}\cdots \\
\cdots \\
\end{array}$ & $\begin{array}{l}\cdots \\
\cdots\end{array}$ & $\begin{array}{l}10,323 \\
11,372 \\
16,542\end{array}$ & $\begin{array}{l}32 \\
81 \\
44\end{array}$ & $\begin{array}{l}15 \\
59 \\
79\end{array}$ & $\begin{array}{l}151 \\
156 \\
342\end{array}$ & $\begin{array}{r}0 \\
49 \\
29\end{array}$ & $\begin{array}{l}12 \\
91 \\
20\end{array}$ & $\begin{array}{r}7 \\
103 \\
44\end{array}$ & $\begin{array}{l}28 \\
72 \\
80\end{array}$ & $\begin{array}{l}100 \\
183 \\
198\end{array}$ & $\begin{array}{l}36 \\
64 \\
38\end{array}$ & $\begin{array}{r}65 \\
156 \\
75\end{array}$ & $\begin{array}{l}144 \\
181 \\
174\end{array}$ & $\begin{array}{l}29 \\
31 \\
21\end{array}$ & $\begin{array}{l}1254 \\
1198 \\
1154\end{array}$ \\
\hline $\begin{array}{l}\text { Stoke-on-Tren } \\
\text { Sunderland } \\
\text { Tynemouth }\end{array}$ & $\begin{array}{c}\text { nt } \\
\cdots \\
\cdots\end{array}$ & $\begin{array}{l}\cdots \\
\cdots \\
\cdots\end{array}$ & $\begin{array}{r}29,246 \\
18,300 \\
7,052\end{array}$ & $\begin{array}{l}52 \\
67 \\
46\end{array}$ & $\begin{array}{r}102 \\
67 \\
50\end{array}$ & $\begin{array}{r}59 \\
349 \\
160\end{array}$ & $\begin{array}{l}52 \\
48 \\
44\end{array}$ & $\begin{array}{r}74 \\
120 \\
81\end{array}$ & $\begin{array}{l}57 \\
90 \\
72\end{array}$ & $\begin{array}{r}110 \\
82 \\
72\end{array}$ & $\begin{array}{l}183 \\
183 \\
111\end{array}$ & $\begin{array}{l}54 \\
69 \\
38\end{array}$ & $\begin{array}{l}131 \\
113 \\
122\end{array}$ & $\begin{array}{l}172 \\
156 \\
152\end{array}$ & $\begin{array}{l}89 \\
28 \\
38\end{array}$ & $\begin{array}{l}1124 \\
1187 \\
1280\end{array}$ \\
\hline $\begin{array}{l}\text { Wakefield } \\
\text { Wallasey } \\
\text { Walsall }\end{array}$ & $\begin{array}{l}\cdots \\
\cdots \\
\cdots\end{array}$ & $\begin{array}{l}\cdots \\
\cdots \\
\cdots\end{array}$ & $\begin{array}{r}7,243 \\
10,882 \\
11,958\end{array}$ & $\begin{array}{l}43 \\
53 \\
37\end{array}$ & $\begin{array}{l}73 \\
33 \\
74\end{array}$ & $\begin{array}{l}90 \\
64 \\
48\end{array}$ & $\begin{array}{l}34 \\
19 \\
40\end{array}$ & $\begin{array}{l}48 \\
20 \\
58\end{array}$ & $\begin{array}{l}25 \\
63 \\
24\end{array}$ & $\begin{array}{l}75 \\
18 \\
95\end{array}$ & $\begin{array}{r}166 \\
95 \\
183\end{array}$ & $\begin{array}{l}59 \\
45 \\
65\end{array}$ & $\begin{array}{r}59 \\
88 \\
152\end{array}$ & $\begin{array}{l}122 \\
142 \\
147\end{array}$ & $\begin{array}{l}20 \\
28 \\
32\end{array}$ & $\begin{array}{l}1021 \\
1212 \\
1064\end{array}$ \\
\hline
\end{tabular}


(contin.)

\begin{tabular}{|c|c|c|c|c|c|c|c|c|c|c|c|c|c|c|c|}
\hline \multirow[b]{2}{*}{ County Borough } & \multirow{2}{*}{\multicolumn{2}{|c|}{$\begin{array}{l}\text { No. of } \\
\text { Males } \\
\text { aged } \\
45-64\end{array}$}} & \multicolumn{3}{|c|}{ Air Pollution } & \multicolumn{4}{|c|}{ Social Index } & \multicolumn{6}{|c|}{ Cause of Death (Rates per 100,000 Males aged 45-64) } \\
\hline & & & $\begin{array}{c}\text { Dom- } \\
\text { estic }\end{array}$ & $\begin{array}{c}\text { Indus } \\
\text { trial }\end{array}$ & \begin{tabular}{|} 
Power \\
Sta- \\
tion
\end{tabular} & $\begin{array}{c}\text { Social } \\
\text { Class }\end{array}$ & $\begin{array}{c}\text { Over } \\
\text { crowd- } \\
\text { ing }\end{array}$ & $\begin{array}{l}\text { Popula- } \\
\text { tion } \\
\text { Den- } \\
\text { sity }\end{array}$ & $\begin{array}{c}\text { Edu- } \\
\text { ca- } \\
\text { tion }\end{array}$ & $\begin{array}{l}\text { Bron- } \\
\text { chitis }\end{array}$ & $\begin{array}{c}\text { Pneu- } \\
\text { monia }\end{array}$ & $\begin{array}{l}\text { Respi- } \\
\text { ratory } \\
\text { Tuber- } \\
\text { culosis }\end{array}$ & $\begin{array}{l}\text { Cancer } \\
\text { of Lung } \\
\text { \& Bron- } \\
\text { chus }\end{array}$ & $\begin{array}{l}\text { All other } \\
\text { Respira- } \\
\text { tory } \\
\text { Diseases }\end{array}$ & $\begin{array}{l}\text { All Non- } \\
\text { Respi- } \\
\text { ratory } \\
\text { Diseases }\end{array}$ \\
\hline $\begin{array}{l}\text { Warrington } \\
\text { West Bromwich } \\
\text { West Ham .. }\end{array}$ & $\begin{array}{l}\cdots \\
\cdots \\
\cdots\end{array}$ & $\begin{array}{r}8,984 \\
9,026 \\
17,086\end{array}$ & $\begin{array}{l}39 \\
35 \\
74\end{array}$ & $\begin{array}{l}91 \\
75 \\
93\end{array}$ & $\begin{array}{r}362 \\
22 \\
346\end{array}$ & $\begin{array}{l}65 \\
44 \\
69\end{array}$ & $\begin{array}{l}70 \\
79 \\
90\end{array}$ & $\begin{array}{r}71 \\
30 \\
134\end{array}$ & $\begin{array}{r}110 \\
94 \\
101\end{array}$ & $\begin{array}{l}245 \\
209 \\
181\end{array}$ & $\begin{array}{l}60 \\
74 \\
67\end{array}$ & $\begin{array}{r}78 \\
136 \\
105\end{array}$ & $\begin{array}{l}183 \\
169 \\
197\end{array}$ & $\begin{array}{l}22 \\
33 \\
34\end{array}$ & $\begin{array}{l}1172 \\
1061 \\
1077\end{array}$ \\
\hline $\begin{array}{l}\text { West Hartlepool } \\
\text { Wigan .. } \\
\text { Wolverhampton }\end{array}$ & $\begin{array}{l}\cdots \\
\cdots\end{array}$ & $\begin{array}{r}7,730 \\
9,764 \\
17,669\end{array}$ & $\begin{array}{l}48 \\
58 \\
40\end{array}$ & $\begin{array}{l}77 \\
84 \\
91\end{array}$ & $\begin{array}{r}0 \\
96 \\
27\end{array}$ & $\begin{array}{l}55 \\
55 \\
33\end{array}$ & $\begin{array}{l}80 \\
72 \\
44\end{array}$ & $\begin{array}{r}118 \\
46 \\
26\end{array}$ & $\begin{array}{r}70 \\
101 \\
79\end{array}$ & $\begin{array}{l}159 \\
236 \\
139\end{array}$ & $\begin{array}{l}43 \\
41 \\
78\end{array}$ & $\begin{array}{r}91 \\
85 \\
125\end{array}$ & $\begin{array}{l}137 \\
126 \\
119\end{array}$ & $\begin{array}{l}39 \\
50 \\
27\end{array}$ & $\begin{array}{l}1173 \\
1272 \\
1021\end{array}$ \\
\hline $\begin{array}{l}\text { Worcester } \\
\text { York . . } \\
\text { Cardiff }\end{array}$ & $\begin{array}{l}\cdots \\
\cdots\end{array}$ & $\begin{array}{r}6,766 \\
12,120 \\
27,199\end{array}$ & $\begin{array}{l}32 \\
37 \\
53\end{array}$ & $\begin{array}{l}48 \\
66 \\
43\end{array}$ & $\begin{array}{l}134 \\
494 \\
239\end{array}$ & $\begin{array}{l}27 \\
35 \\
33\end{array}$ & $\begin{array}{l}38 \\
24 \\
55\end{array}$ & $\begin{array}{l}17 \\
33 \\
88\end{array}$ & $\begin{array}{l}60 \\
60 \\
53\end{array}$ & $\begin{array}{r}93 \\
126 \\
126\end{array}$ & $\begin{array}{l}42 \\
37 \\
44\end{array}$ & $\begin{array}{r}110 \\
68 \\
116\end{array}$ & $\begin{array}{l}116 \\
106 \\
159\end{array}$ & $\begin{array}{l}17 \\
19 \\
28\end{array}$ & $\begin{array}{r}985 \\
1108 \\
1225\end{array}$ \\
\hline $\begin{array}{l}\text { Merthyr Tydfil } \\
\text { Newport } \quad \text {. } \\
\text { Swansea } \quad \text {.. }\end{array}$ & $\begin{array}{l}\ldots \\
\cdots\end{array}$ & $\begin{array}{r}7,396 \\
12,119 \\
18,996\end{array}$ & $\begin{array}{l}65 \\
36 \\
29\end{array}$ & $\begin{array}{l}10 \\
78 \\
69\end{array}$ & $\begin{array}{r}8 \\
946 \\
42\end{array}$ & $\begin{array}{l}53 \\
45 \\
47\end{array}$ & $\begin{array}{l}39 \\
62 \\
48\end{array}$ & $\begin{array}{l}28 \\
53 \\
23\end{array}$ & $\begin{array}{l}62 \\
59 \\
62\end{array}$ & $\begin{array}{l}182 \\
121 \\
144\end{array}$ & $\begin{array}{l}50 \\
31 \\
35\end{array}$ & $\begin{array}{r}110 \\
106 \\
98\end{array}$ & $\begin{array}{l}129 \\
172 \\
184\end{array}$ & $\begin{array}{r}131 \\
34 \\
33\end{array}$ & $\begin{array}{l}1234 \\
1134 \\
1175\end{array}$ \\
\hline
\end{tabular}

